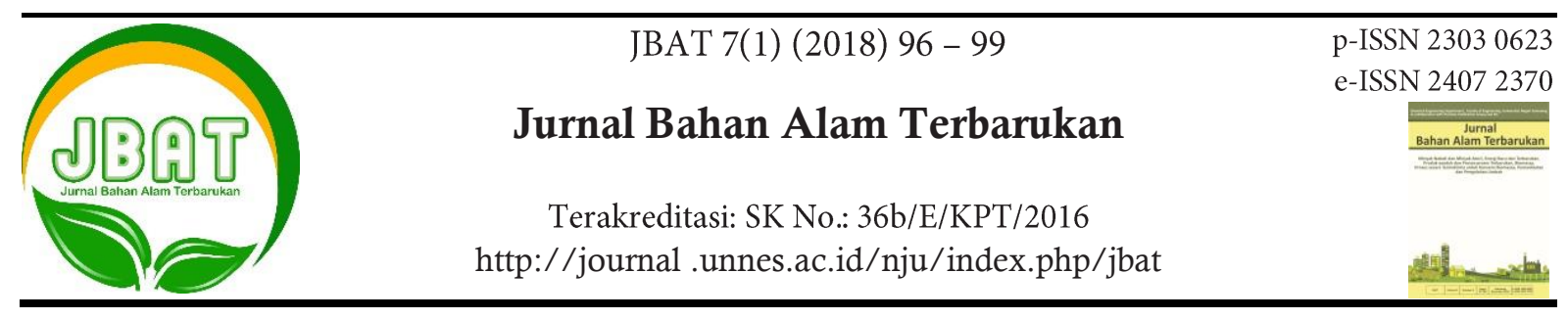

\title{
Starch Production from Red Ginger (Zinggiber officinale Rosc.)
}

\author{
Widayat $^{1}$, H Satriadi $^{1}$, Syaiful $^{2}$, Atik Kurnia $^{1}$, Faradilla Driastuti $^{1, \bigotimes}$
}

\section{DOI 10.15294/jbat.v7i1.11417}

${ }^{1}$ Department of Chemical Engineering, Faculty of Engineering, Diponegoro University, J1. Prof. Soedarto, SH, Tembalang, Semarang 50275

${ }^{2}$ Department of Mechanical Engineering, Faculty of Engineering, Diponegoro University, J1. Prof.

Soedarto, SH, Tembalang, Semarang 50275

\begin{tabular}{l} 
Article Info \\
\hline Article history: \\
Received \\
$\quad$ October 2017 \\
Accepted \\
May 2018 \\
Published \\
$\quad$ June 2018 \\
\hline Keywords : \\
Yield; Red ginger; \\
Red ginger starch; \\
Yield; \\
Settling time; \\
Temperature
\end{tabular}

\begin{abstract}
Red Ginger is a natural ingredient including to spice that contain starch $40-60 \%$ weight. Application of red ginger usually it is taken its extract or to taste of traditional food. The purpose of this research is to know the influence of settling time, the red ginger and solvent ratio, and the temperature of the solvent in the production process of red ginger starch. We hope to get the best condition to get the highest starch yield. The process of making red ginger starch begins with peeled, then washed, shredded, filtered and precipitated. Starch ginger dried by the sun's heat. The best result was obtained at 1 hour sedimentation time with red ginger starch yield $13,3 \%$, red ginger and water ratio $3: 5(\mathrm{~g} / \mathrm{g})$ with yield of red ginger $15,69 \%$ and temperature of solvent at $25^{\circ} \mathrm{C}$ with yield of red ginger starch $11.17 \%$.
\end{abstract}

* This is a revised and extended version of an article which had been presented at SNTK UNNES 2017, Semarang, Indonesia, September 20 $0^{\text {th }}, 2017$.

\section{INTRODUCTION}

Indonesia is an agrarian country which rich of natural wealth. But we still import some of food commodities caused by the growth population with no increase in food production (Pangesti, 2009). Based on the survey conducted (MITI, 2013) throughout the 2012, one of the foodstuffs still imported by Indonesia is wheat grain with 6.3 million tons and wheat flour as much as 497.7 thousand tons. In Indonesia. Wheat is used as raw material for the bakery, macaroni, noodles and others. Carbohydrate sources in Indonesia are available quite a lot, including those from tubers. According to Pangesti (2009) the advantages of tuber types are: 1) can be stored at least in processed form between in the form of starch and flour, 2) can grow in marginal area where other plants cannot grow, 3) can be applied not limited only to the bulbs, e.g. leaves of cassava and sweet potato. One type of tubers are quite a lot in Indonesia is red Ginger (Zingiber officinale var rubrum).

Red ginger (Zingiber officinale Rosc) is one of the commodities of herbs and medicine is also a priority crop in the findings. High market demand both at home and abroad (Yuliani \& Kailaku, 2009). But it still less and simple in application that is used as cooking spice, smell and taste of the food products (Koeswara, 1995). In addition to cough, rheumatism, headache and useful for women who have just given birth (Rodriquez, 1971). Though this ginger plant has high antioxidant activity. Red ginger contains volatile oil components (volatile oil), called essential oil. It is a typical odor component. It also contains non-volatile oil

(C) 2018 Semarang State University

\footnotetext{
${ }^{\square}$ Corresponding author:

Department of Chemical Engineering, Faculty of Industrial Technology,

Universitas Ahmad Dahlan, J1. Supomo, Janturan, Yogyakarta 55164

E-mail: lukhi.mulia@che.uad.ac.id
}

ISSN 2303-0623 


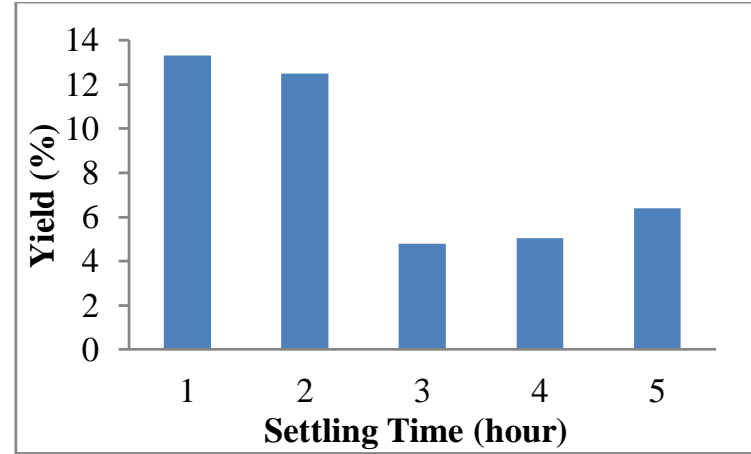

Figure1. Effect of settling time to the value of red ginger starch yield.

(commonly called oleoresin), a component of a spicy and bitter taste (Bustan et al., 2008).

In addition, ginger tubers also have a fairly large starch, which is about $40-60 \%$ by weight (Sazalina, 2005). So far, its application is only limited to taking the juice. So that starch content has not been used. Starch of red ginger is the result of the ginger extract deposition process. In this study observed various variables to obtain maximum yield of starch from ginger tuber. By utilizing red ginger starch (Zingiber officinale var rubrum) is expected to increase food diversification in Indonesia. It also can provide added value for instant ginger entrepreneurs. The use of red ginger starch can make food products produced as one type of functional food, because it contains bioactive components that can give a positive effect on the function of human metabolism (Hartati, 2012). In addition, ginger processing in the form of starch is one way of preserving the harvest, increase the shelf life and maintain or improve the quality of nutritional value (Sugiarto et al., 2007).

\section{RESEARCH METHODOLOGY}

The stage of making red ginger starch begins with the collection of raw material. The material is obtained from farmers in Batang regency, Central Java. Subsequently performed soaking for cleansing of red ginger from the soil and softening process of red ginger meat so easy to clean the skin. Further done to clean the red ginger from the soil and softening process of it and make it easy to clean. And then it is peeled and shredded using a machine. The next step is the process of making red ginger starch. The result of the grater is filtered while given water (aquadest) as solvent to extract starch from it. The process of making starch with variation of settling time (1 hour, 2 hours, 3 hours, 4 hours, and 5 hours) and the red ginger and water

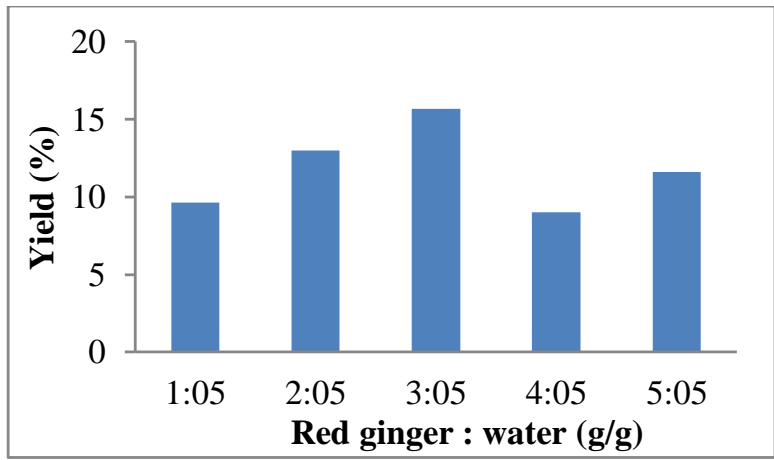

Figure 2. The effect of red ginger and water ratio to the value of red ginger starch yield.

ratio $(0.2,0.4,0.6,0.8$ and 1,0$)$. After doing the data processing, then we get the best settling time and the ratio of red ginger to water, which give the highest yield. The best settling time and ratio of red ginger to water then it is used to make red ginger starch with water temperature variation $\left(25^{\circ} \mathrm{C}, 40\right.$ ${ }^{\circ} \mathrm{C}, 55^{\circ} \mathrm{C}, 70^{\circ} \mathrm{C}$, and $\left.85^{\circ} \mathrm{C}\right)$.

\section{RESULT AND DISCUSION}

Yield is an important parameter to know the economic value and effectiveness of a product or material process. The calculation of the yield is based on the percentage comparison between the final weight and the initial weight of the process. The greater the yield, the higher the economic value of the product, as well as the effectiveness of the (Yunita et al., 2012).

Figure 1 shows the process of making red ginger starch with a ratio of red ginger 0.6 ; water temperature $55{ }^{\circ} \mathrm{C}$ and the effect of different precipitation time to get the best settling time. The best precipitation time is will give the highest yield. It will be used for starch making with the effect of red ginger ratio: water and water temperature vary. The more time the settling time of the yield is decreased from 1 hour to 3 hours then increase again in 4 hours and 5 hours. The optimum settling time produced in the study of red ginger starch production was 1 hour and give $13.3 \%$ yield. The yield tends to decrease when the sedimentation takes 2-5 hours.

Figure 2 shows the results of red ginger starching time of 1 hour sedimentation, water temperature $55^{\circ} \mathrm{C}$ and the influence of red ginger and water ratios. The effect of red and water ginger ratios ratio shows a fluctuating effect on the average yield of red ginger starch produced. In the red ginger and water ratio $1: 5,2: 5$, and $3: 5$, the yield is increased. The increase of yield along with the 


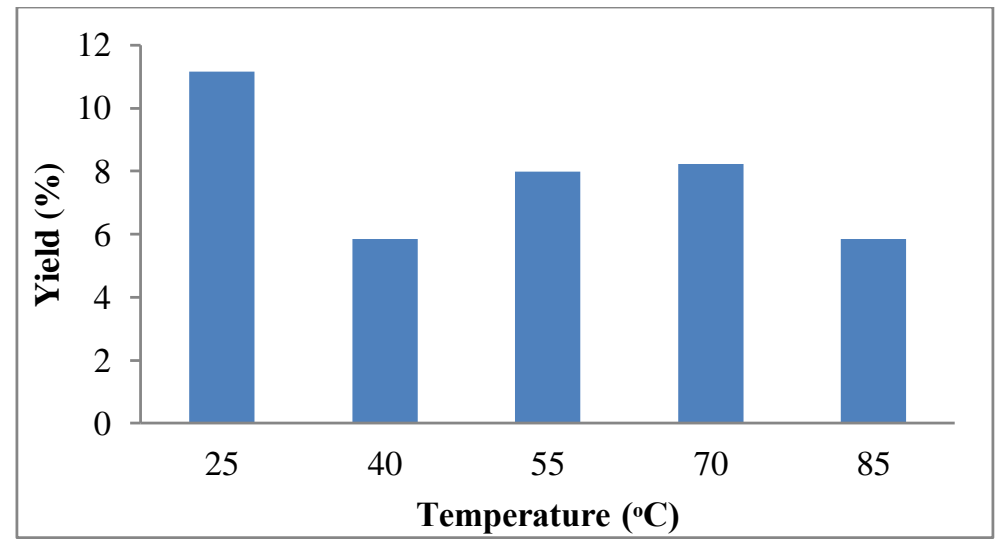

Figure 3. The effect of water temperature to the value of red ginger starch yield.

increasing ratio of red ginger and water due to red ginger used is also greater than the water as a solvent so that the starch dissolves during more extortion. In the ratio of 4: 5 the value of yield decreased because due to red ginger more but water as the solvent did not increase, so starch can dissolved maximally. The ratio of red ginger and water that give the highest yield value, it is used for the process of making red ginger starch with the influence of different water temperature.

Figure 3 shows the effect of water temperature to the value of red ginger starch yield. It shows the fluctuated yield in some different temperature. The highest yield occurs at $25{ }^{\circ} \mathrm{C}$ or without heating. This is because the increasing temperature, the starch will be dissolved so it can not settle into starch deposition. Low yield value is influenced by temperature, this is because the temperature is a factor that can accelerate the dissolution of red ginger extract that will precipitate to be starch.

The relatively low yield value is also caused by the amount of starch which is wasted during the sieving process. Water heating as a solvent to extract the starch from red ginger causes the structure of starch tissue to become brittle and crumbled, and it make many starch organic components being dissolved and decreasing at the time of precipitation (Yunita, 2012). The low yield is also due to the effects of drying, where drying is the process of discharging or discharging liquid from a material which includes drying, roasting, evaporating and others. The final result of drying is a material free of water (liquid) or low amount of water (Yunita 2012). Water content usually decrease to $60-70 \%$ with drying and resulting in low yield value.

\section{CONCLUSION}

The results of this study indicate that the best result obtained on 1 hour settling time with yield value $13.3 \%$, red ginger and water ratio of $3: 5$ $(\mathrm{w} / \mathrm{w})$ with yield value $15.69 \%$ and the best solvent temperature is $25^{\circ} \mathrm{C}$ with starch yield value $11.17 \%$.

\section{REFERENCES}

Hartati, M. E. 2012. Pengaruh Penambahan Pati Jahe Hasil Samping Pembuatan Jahe Instan Pada Mutu Kue Kering. Jurnal Rekapangan. 1(6): 24 - 31.

Koeswara, S. 1995. Jahe dan Hasil Olahannya. Pustaka Sinar Harapan, Jakarta.

M I T I. 2013. Masyarakat Ilmuwan dan Teknologi Indonesia. 10 Bahan Pangan Indonesia Masih Impor. http://berandamiti.com/10-bahan-pangan-masih-impor (accessed on 20 Agustus 2017).

Bustan, M. D., Febriyani, R., Pakpahan, H. 2008. Pengaruh Waktu Ekstraksi Dan Ukuran Partikel Terhadap Berat Oleoresin Jahe Yang Diperoleh Dalam Berbagai Jumlah Pelarut Organik (Methanol). Jurnal Teknik Kimia. 4(15): 16-26.

Pangesti, L. T. 2009. Pemanfaatan Pati Ganyong (Canna edulis) Pada Pembuatan Mie Segar Sebagai Upaya Peanekaragaman Pangan Non Beras. Media Pendidikan, Gizi, dan Kuliner. 1(1): 1-6.

Rodriquez D. W. 1971. Ginger Comodity. Buletin A. Agriculture Planning Unit, Jamaica: 3839.

Sazalina. 2005. Optimisation of Operating Parameters For The Removal Of Ethanol From Zingiber Officinale Roscoe (Ginger) 
Oleoresin Using Short-Path Distillation. Master Thesis. Faculty of Chemical and Natural Resources Engineering Universiti Teknologi Malaysia. 42-46.

Yuliani, S., Kailaku, S. I. 2009. Pengembangan Produk Jahe Kering Dalam Berbagai Jenis Industri. Balai Besar Penelitian dan Pengembangan Pascapanen Pertanian. Buletin Teknologi Pascapanen Pertanian. 1(5): 61-68.

Sugiarto, S., Indah, Y., Tedy, T. 2007. Pendugaan Umur Simpan Bubuk Jahe Merah (Zingiber officinale var. rubrum). Departemen Teknologi Industri Pertanian, Fakultas Teknologi Pertanian - IPB. Jurnal Teknologi Industri Pertanian. 17(1): 7-11.

Yunita, D., Lubis, Y. M., Nurakamal, N. 2012. Pembuatan $\mathrm{Mi}$ Kering dengan Menggunakan Tepung Labu Tanah (Cucurbita moschata). Jurnal Teknologi Pangan. Jurusan Teknologi Hasil Pertanian. 2(11): 1-11. 